\title{
THERMAL BOWING OF REINFORCED CONCRETE ELEMENTS EXPOSED TO NON-UNIFORM HEATING
}

\section{R. KOWALSKI ${ }^{1}$, M. GLOWACKI ${ }^{2}$, J. WRÓBLEWSKA ${ }^{3}$}

\begin{abstract}
The paper presents the test description and results of thermal bowing of RC beams exposed to non-uniform heating at high temperature. Bending of a non-uniformly heated element is caused by free thermal elongation of the material it is made of. The higher the temperature gradient, the greater the bending. In the case when an element is exposed to load and high temperature simultaneously, apart from free bending also deformation of the RC element may occur, which is caused by the decrease of the concrete or reinforcing steel mechanical properties. In order to examine the contribution of the deflection caused by thermal bowing to the total deformation of the bent element with a heated tension zone, an experimental study of freely heated (unloaded) beams was performed. RC beams were heated: (1) on three sides of the cross-section or (2) only on the bottom side. Deflection of elements loaded by a substitute temperature gradient was calculated using the Maxwell-Mohr formula. The test results show that deflection of freely heated RC beams (caused by the thermal bowing phenomenon) can be 10 to $20 \%$ of the total deflection of loaded RC beams with a heated tension zone.
\end{abstract}

Keywords: RC beams, high temperature, fire, deflection, thermal bowing, temperature gradient

\footnotetext{
${ }^{1}$ DSc., PhD., Eng., Associate professor, Warsaw University of Technology, Faculty of Civil Engineering, ul. Lecha Kaczyńskiego 16, 00-637 Warsaw, Poland, e-mail: r.kowalski@il.pw.edu.pl

${ }^{2} \mathrm{PhD}$., Eng., Warsaw University of Technology, Faculty of Civil Engineering, ul. Lecha Kaczyńskiego 16, 00-637 Warsaw, Poland, e-mail: m.glowacki@il.pw.edu.pl

${ }^{3}$ MSc., Eng., Warsaw University of Technology, Faculty of Civil Engineering, ul. Lecha Kaczyńskiego 16, 00-637 Warsaw, Poland, e-mail: j.wroblewska@il.pw.edu.pl
} 


\section{INTRODUCTION}

Bent or compressed reinforced concrete (RC) elements, which constitute a part of complex concrete structures, i.e. multi-span slabs or beams and columns or walls, can be exposed to fire from the side of either the tension or compression zone [1,2]. The redistribution of internal forces caused by significant changes in the cross-sections' stiffness with a heated tension or compression zone plays a major role in the analysis of complex RC structures exposed to fire [3, 4]. The effect of the redistribution of internal forces is usually beneficial for multi-span $\mathrm{RC}$ elements heated on the bottom side. This is due to unloading of span cross-sections and loading of the corresponding support crosssections (sagging moments decrease and hogging moments increase). Bending of each non-uniformly heated element is caused by free thermal elongation of the material it is made of. The higher the temperature gradient, the greater the bending. This phenomenon is called thermal bowing [5] and occurs independently of the element load level. In statically indeterminate bending members, thermal bowing can result in the occurrence of additional internal forces, while in compressed elements (columns) it can lead to increase of the eccentricity of the axial force. In the case when an element is exposed to load and high temperature simultaneously, apart from free bending also deformation of the RC element may occur, which is caused by decrease of the concrete or reinforcing steel mechanical properties in these conditions. The reaction of the element cross-section heated from the compression zone (heated concrete) differs from that of the cross-section heated from the tension zone (heated tensile reinforcing bars) [3].

The deformation of elements in which the tension zone is heated is determined by the total strain of the reinforcement which is loaded and heated simultaneously. The total strain can be expressed as the sum of two components: (1) free thermal elongation of steel and (2) strain caused by the reduction of its mechanical properties due to the simultaneous influence of load and high temperature. The total strain of the reinforcement can be determined using the stress-strain relationships of tensile steel at high temperature introduced in [6-8]. These relationships have been developed using a model of reinforcing steel behaviour at high temperature proposed by Anderberg [9], given in Eurocode [10]. It adequately illustrates the reinforcement reaction to fire conditions. A comparison of this model with experimental results is presented in [11]. 
However, deformations of elements with a heated compression zone depend on the total strain of the concrete. This strain results from the simultaneous occurrence of two phenomena:

- $\quad$ free thermal elongation of concrete [10], and

- contraction of compressed concrete caused by the reduction of its mechanical properties due to the influence of load and high temperature (the phenomenon known as load-induced thermal strain or transient creep [12-17]).

The aforementioned phenomena cause opposite deformation of elements in which the compression zone is heated. Thermal bowing of an element plays the major role at the initial heating stage. During that time, the element usually bends in a direction opposite to the deformation caused by load. Concrete in the compression zone starts to react to the load at the later heating stage [18-21] and then the element bends in the direction of the load.

Diagrams of the total strain of heated concrete under load can be found in [21]. The total strain of concrete was estimated as a superposition of its components, including free thermal strain and loadinduced thermal strain (according to Eurocode model [10]). These diagrams can be useful for estimating the total strain of concrete in RC elements exposed to load and high temperature (from the compression zone side) simultaneously. Diagrams of the stress-strain relationships of heated concrete under load can also be found in [22].

The behaviour of compressed RC elements exposed to non-uniform heating has been poorly investigated. The majority of studies focus on bent RC elements subjected to non-uniform heating [5, 23-27]. In most cases, these are tests of single-span bent members with a heated tension zone (reinforcement). The test results show that the total deflection/span length ratio $(d / l)$ is about 1/43-1/12 at high temperature. The number of studies of multi-span elements [28, 29], elements with a heated compression zone [3, 28] or exposed to high temperature on all sides simultaneously [26] is limited.

From the test results of the deformation of heated elements under load, it is not possible to extract components caused by thermal bowing as well as the decrease of the mechanical properties of the materials due to the influence of high temperature (load-induced thermal strain in the case of a heated compression zone, or total elongation of reinforcement in the case of a heated tension zone).

In order to determine the contribution of the deflection caused by thermal bowing to the total deformation of a non-uniformly heated element, an experimental study of freely heated (unloaded) $\mathrm{RC}$ beams was performed. The beams were heated in two ways: 
(1) on three sides of the cross-section; in this way a beam with heated bottom and lateral surfaces or a non-uniformly heated free-standing column was simulated; there is a two-way unsteady heat transfer in the cross-section,

(2) only on one side (isolated lateral surfaces); in this way a slab or a wall with one heated side or a column in a wall with good insulating properties was simulated.

\section{EXPERIMENTAL STUDY}

\subsection{ELEMENTS}

Seven reinforced concrete beams $160 \times 200 \mathrm{~mm}$ in cross-section and $1300 \mathrm{~mm}$ in length (Fig. 1), made of $\mathrm{C} 35 / 45$ concrete with gravel (siliceous) aggregate, were examined. The average compressive strength of the concrete determined on $150 \mathrm{~mm}$ cubes was $46.3 \mathrm{MPa}$ after 28 days from casting and $60.8 \mathrm{MPa}$ after about 4 months, before testing (an increase of strength by about $31 \%$ ). In order to prevent unexpected cracking, the elements were reinforced with $8 \mathrm{~mm}$ diameter bars made of steel with a characteristic yield strength of $500 \mathrm{MPa}$. The average yield strength of reinforcement determined experimentally was $560 \mathrm{MPa}$.

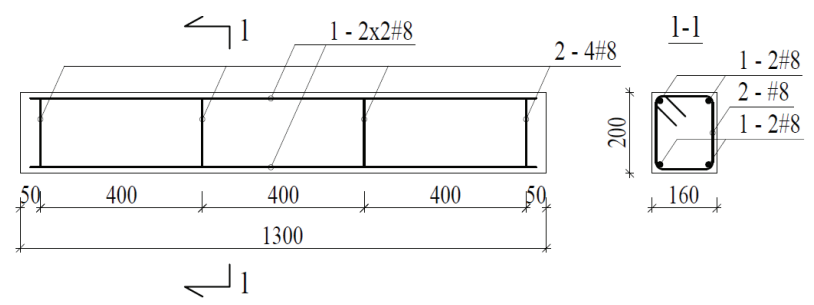

Fig. 1. Beams dimensions and reinforcement

\subsection{HEATING PROCEDURE}

The beams were divided into two groups. In the first group three elements were heated on three sides of the cross-section (from the bottom and from the lateral surfaces; Fig. 2a; a two-way heat transfer). Prior to heating, each of the three elements was loaded and unloaded seven times to obtain $50 \%$ of the calculated load-bearing capacity. This was to cause cracking of the beams and to simulate the conditions of the quasi-permanent combination of actions. The beams were unloaded during heating. All elements were tested at high temperature for 240 minutes. 
In the second group four identical beams were heated only from the bottom (Fig. 2b; a one-way heat transfer in the cross-section) after insulation of the lateral surfaces. In this way, one-sided heating of such elements as slabs or walls was simulated. The beams were uncracked before the high-temperature tests and were also unloaded during heating. The elements were heated for 60,120 , 180 or 240 minutes.

An electric height-adjustable furnace was used for the beams testing. The furnace chamber was heated to a temperature of about $500{ }^{\circ} \mathrm{C}$. Then, depending on the way of heating, the furnace was placed under the beam and elevated to half of the element height (Fig. 2a) or positioned directly under the beam (Fig. 2b). Thermal insulation made of ceramic wool was fixed to the lateral surfaces of the element above the furnace. During the first 50 minutes of heating, the temperature in the furnace chamber increased to about $900-1000{ }^{\circ} \mathrm{C}$ and its value remained within this range until the end of the test. The test stand is shown in Fig. 2c.

a)

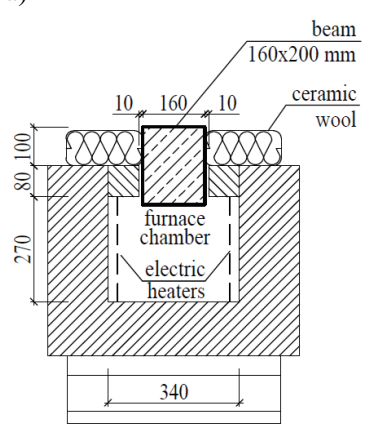

b)

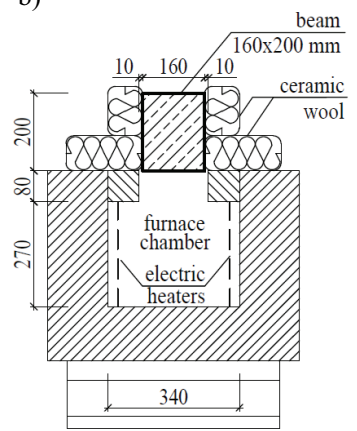

c)

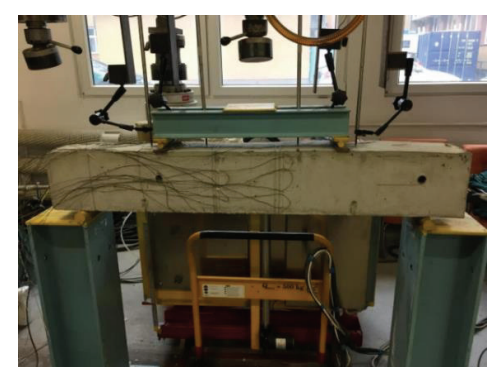

Fig. 2. Beam location in the furnace chamber: a) beam heated on three sides, b) beam heated on one side (from the bottom), c) the test stand (furnace visible behind the beam)

During the tests the following parameters were recorded:

- time of heating from the moment at which the furnace was placed under the element,

- $\quad$ beam deflection measured using four sensors located on the top surface (Fig. 3),

- temperature in the furnace chamber,

- $\quad$ temperature on the element surfaces and at selected points in the beam cross-section (Fig. 4). 


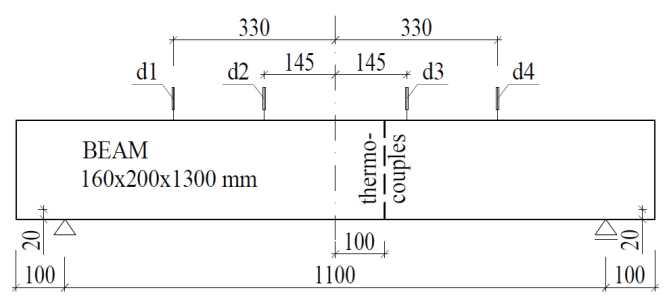

Fig. 3. Location of the measuring equipment a)

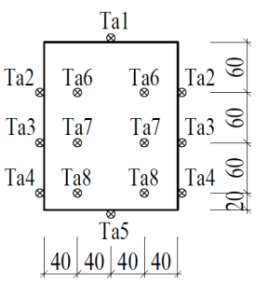

b)

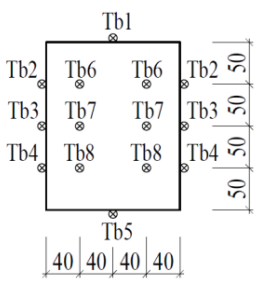

Fig. 4. Temperature measurement points in the cross-section of beam heated: a) on three sides, b) on one side (from the bottom)

\section{THERMAL ANALYSIS OF TESTED BEAMS}

\subsection{TEMPERATURE DISTRIBUTION IN BEAMS CROSS-SECTION}

The temperature was measured at particular points of the beam cross-section (see Fig. 3). Finite element method (FEM) calculations were performed in order to determine the isotherm layout in the heated cross-section.

The SAFIR software [30] was used to calculate the temperature distribution. A two-dimensional model of the beam cross-section made of orthogonal four-node elements with a side width of $10 \mathrm{~mm}$ was considered. It was assumed that heat could penetrate into the element's section through the bottom edge and part of the lateral edges (a two-way heat transfer in the cross-section) or only through the bottom edge (a one-way heat transfer in the cross-section). The thermal properties of concrete (specific heat and thermal conductivity) were adopted on the basis of [10]. The temperature values measured at the heated beams' surface were used as input data for the FEM calculations. In this way, the effect of radiation in the furnace chamber on the heated surface of the element, which is difficult to estimate, was eliminated. 
a)

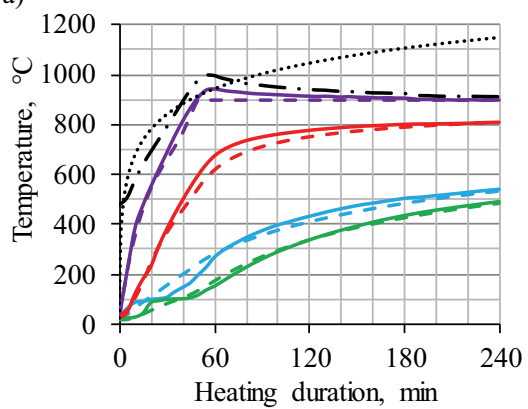

........ Standard curve

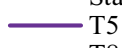

$-\mathrm{T} 8$

$\mathrm{T} 3$
$\mathrm{~T} 7$ b)

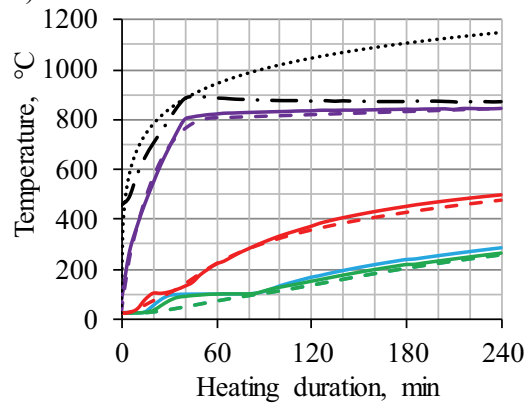

- - Furnace chamber

$---\mathrm{T} 5-\mathrm{FEM}$

- - - T8-FEM

$---\mathrm{T} 3-\mathrm{FEM}$

- - T7-FEM

Fig. 5. Temperature at particular points of the beam cross-section - comparison of test results and FEM calculations: a) beam heated on three sides, b) beam heated on one side (from the bottom)

Figure 5 shows the results of the temperature measurement (solid lines) and FEM calculations (dashed lines) at particular points of the beam cross-section (points: T3, T5, T7 and T8 - Fig. 4) superimposed on the furnace chamber temperature and standard curve [31]. The results of the calculations were consistent with the test results. Hence, it can be concluded that the calculated temperature fields are reliable. Figure 6 presents the temperature distribution in the heated cross-section after 60, 120 and 240 minutes.

a)
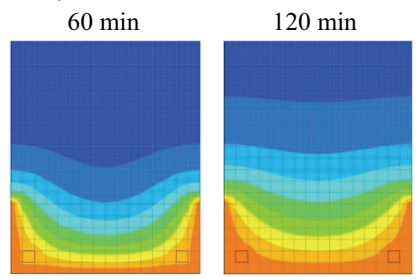

b)

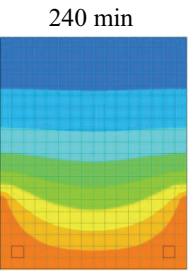

$60 \mathrm{~min}$
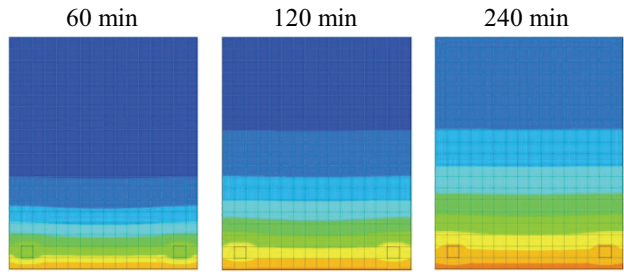

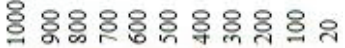

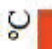

Fig. 6. Isotherm layout in the beam cross-section heated: a) on three sides, b) on one side (from the bottom) 


\subsection{EXTRACTION OF SUBSTITUTE TEMPERATURE GRADIENT}

As a result of the unsteady heat transfer, a nonlinear temperature distribution develops in the crosssection. The determination of the response of the structural element to the effect of high temperature requires an advanced analysis. In order to obtain data to perform simplified calculations, three components were extracted from the nonlinear temperature distribution [32]:

(1) linear, steady;

(2) linear, symmetric with respect to the central, horizontal axis of the cross-section;

(3) nonlinear, so-called "self-equilibrated".

The first and second components determine the thermal response of the structural elements. The linear components cause only deformations (elongation and bending) of statically determinate structures. In statically indeterminate structures, they cause deformations and the occurrence of additional internal forces. The third, nonlinear component cannot cause any deformation of the element, but only internal stresses in the cross-section [32].

In the case of beams with only the bottom side heated (one-way heat transfer in the cross-section), the nonlinear temperature distribution was approximated by a polynomial function of degree 6 . The use of this function results in a satisfactory convergence with the FEM calculation [32]. The polynomial function of degree 6 can be expressed as a sum of the linear (the sum of linear components (1) and (2)) and the nonlinear function (component (3)). The average temperature value and substitute temperature gradient were extracted from the linear component. These parameters can be used to perform simplified calculations of the deformations of elements subjected to fire.

The two-way heat transfer in the cross-section occurs in the case of beams with three sides heated and leads to a faster increase of temperature at the lateral surfaces and slower increase in the central part of the cross-section (see Fig. 6a). Nevertheless, the heat transfer is symmetric with respect to the central, vertical axis of the cross-section and it does not cause the element to bend to the sides (in the cross-section plane). In order to approximate the temperature distribution with a polynomial function, average temperature values in subsequent horizontal rows of finite element nodes were calculated. Hence, the two-way temperature distribution (Fig. 6a) was replaced with the one-way distribution (i.e. with a horizontal isotherm layout, as in beams heated only from the bottom). Thus, the nonlinear temperature distribution could be approximated by a polynomial function of degree 6 .

Figure 7 shows the linear components extracted from the nonlinear temperature distribution after 30 , $60,90,120,180$ and 240 minutes of heating. For instance, the nonlinear temperature distribution in the cross-section approximated by a polynomial function of degree 6 , as well as the nonlinear "self- 
equilibrated" component extracted from it after 60 minutes of heating, are also shown. After summing up the green curve (non-linear component) and the blue one (linear component), the red curve (nonlinear temperature distribution) is obtained. Tables 1 and 2 show the values of the temperature gradient and average temperature in the cross-section of the tested beams, determined on the basis of Fig. 7.

a)

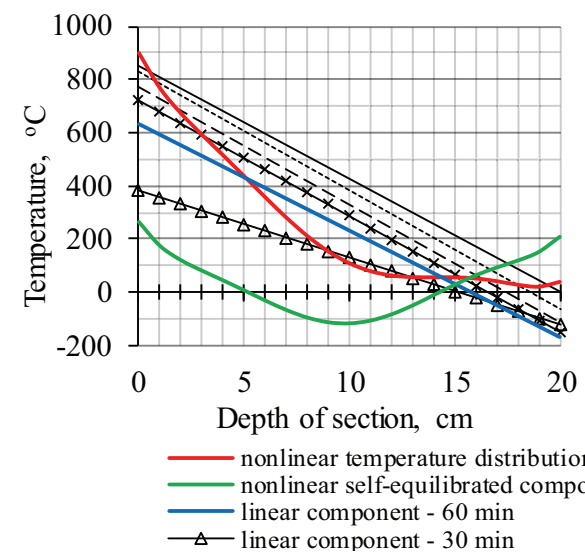

b)

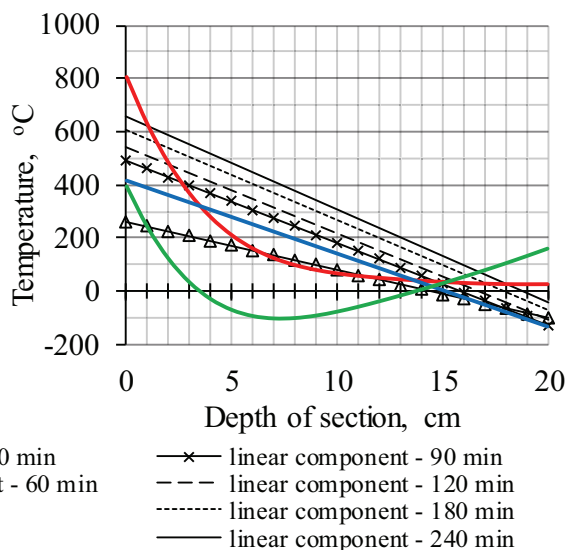

Fig. 7. Linear components of temperature distribution in the beam cross-section heated: a) on three sides,

b) on one side (from the bottom). Nonlinear temperature distribution (red line) and nonlinear "selfequilibrated" component (green line) after 60 minutes are presented

\section{ANALYSIS OF BEAMS DEFLECTION}

\subsection{COMPARISON OF TEST RESULTS AND CALCULATIONS}

Tables 1, 2 and Fig. 8 show a comparison of the tested beams' maximum deflection values obtained in two ways: (1) experimentally determined and (2) calculated on the basis of the temperature gradient specified in section 3.2. In the case of the one-way heat transfer in the cross-section (Fig. 8b), only the deformations of a beam heated for 120 minutes were analyzed, because the results for longer heating times were lost due to an equipment failure. 
Table 1. Temperature gradient, average cross-section temperature and comparison of deflections of the beams heated on three sides for 240 minutes

\begin{tabular}{|c|c|c|c|c|}
\hline $\begin{array}{c}\text { Heating } \\
\text { duration } \\
{[\mathrm{min}]}\end{array}$ & & $\Delta \theta\left[{ }^{\circ} \mathrm{C}\right]$ & $\theta_{a v}\left[{ }^{\circ} \mathrm{C}\right]$ & \multicolumn{2}{|c|}{ Deflection $[\mathrm{mm}]$} \\
\cline { 4 - 5 } & & & Exp. & Calc. \\
\hline 30 & 503 & 128 & 3.7 & 4.0 \\
\hline 60 & 800 & 230 & 6.5 & 6.4 \\
\hline 90 & 872 & 286 & 6.7 & 6.9 \\
\hline 120 & 889 & 326 & 6.9 & 7.1 \\
\hline 180 & 892 & 382 & 7.2 & 7.1 \\
\hline 240 & 855 & 427 & 7.6 & 6.8 \\
\hline
\end{tabular}

a)

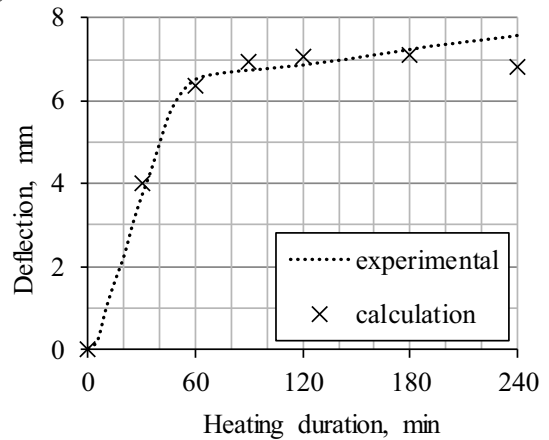

Table 2. Temperature gradient, average cross-section temperature and comparison of deflections of the beam heated on one side (from the bottom) for 120 minutes

\begin{tabular}{|c|c|c|c|c|}
\hline $\begin{array}{c}\text { Heating } \\
\text { duration } \\
{[\mathrm{min}]}\end{array}$ & $\Delta \theta\left[{ }^{\circ} \mathrm{C}\right]$ & $\theta_{a v}\left[{ }^{\circ} \mathrm{C}\right]$ & \multicolumn{2}{|c|}{ Deflection [mm] } \\
\cline { 4 - 5 } & & & Exp. & Calc. \\
\hline 30 & 362 & 80 & 3.0 & 2.9 \\
\hline 60 & 550 & 141 & 4.4 & 4.4 \\
\hline 90 & 618 & 182 & 4.7 & 4.9 \\
\hline 120 & 648 & 215 & 4.9 & 5.2 \\
\hline
\end{tabular}

b)

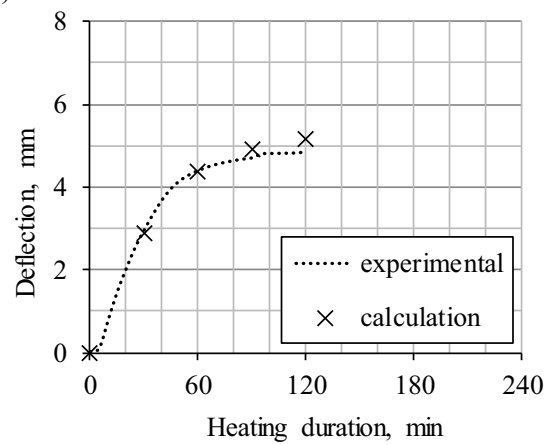

Fig. 8. Comparison of the maximum deflection values obtained in the tests and calculated: a) beams heated on three sides, b) beams heated on one side (from the bottom)

The experimentally determined maximum deflection (Tables 1, 2 and Fig. 8) was calculated on the basis of the results of measurements carried out with sensors located 145 and $330 \mathrm{~mm}$ from the axis of symmetry of the element (see Fig. 3). It was assumed approximately that the deformed axis of the tested beam section is a part of the circle.

The Maxwell-Mohr formula was used to calculate the beam maximum deflection caused by the substitute temperature gradient $(\Delta \theta$; Tables 1,2$)$ :

$$
\overline{1} \cdot d=\int_{0}^{l} \frac{\bar{M} \alpha_{\theta} \Delta \theta}{h} d x
$$

where:

$\overline{1}$ - virtual unit load applied in the direction of the displacement sought, $d$ - maximum deflection, $l$ - span length of the element, $\bar{M}$ - bending moment induced by the virtual load, $\alpha_{\theta}$ - linear coefficient of thermal expansion of concrete, $\Delta \theta$ - temperature gradient in the cross-section, $h$ - cross-section height 
At room temperature, the thermal expansion coefficient of concrete in formula (4.1) can be taken as a constant, equal to $\alpha_{20 C}=1.00 \cdot 10^{-5} \mathrm{~K}^{-1}$ [33]. In fire conditions, the free thermal expansion of materials depends on the temperature. Fig. 9 shows diagrams of the thermal elongation $(\Delta l / l)$ of concrete with two types of aggregate as well as reinforcing steel [10]. It can be seen that in the range from room temperature to about $500{ }^{\circ} \mathrm{C}$ the thermal elongation of reinforcing steel and concrete with siliceous aggregate is comparable.

The average concrete temperature range in the tested elements was about $100-400{ }^{\circ} \mathrm{C}$ (Tables 1,2$)$. In order to estimate the thermal elongation of concrete corresponding to such heating conditions, the coefficient $\alpha_{\theta}$ was determined for the average temperature value of $250{ }^{\circ} \mathrm{C}$. For this purpose, a straight line (dotted), tangential to the diagram of thermal elongation of concrete with siliceous aggregate at the point corresponding to the temperature of $250^{\circ} \mathrm{C}$, was applied in Fig. 9. The thermal expansion coefficient of concrete in heated beams was determined as a tangent of the angle between this line, and the horizontal axis; $\alpha_{\theta}=1.05 \cdot 10^{-5} \mathrm{~K}^{-1}$ was obtained.

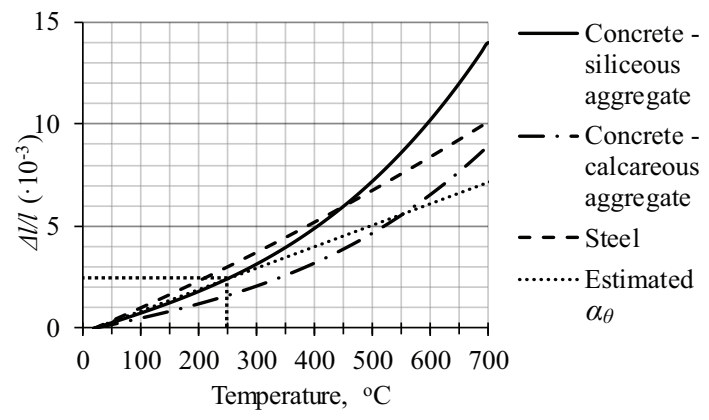

Fig. 9. Free thermal elongation of concrete and steel [10]; estimation of the coefficient $\alpha_{\theta}$

\subsection{DISCUSSION OF THE RESULTS}

Comparing the maximum deflection values shown in Tables 1, 2 and Fig. 8, it can be seen that for both ways of heating the beams, the average difference between the experimentally determined and calculated deflections does not exceed 5\%. This leads to the conclusion that a reliable forecast of the free bending of (unloaded) reinforced concrete elements exposed to fire conditions can be provided by using a simple calculation method (presented in section 4.1), which consists in determining the element deflection caused by the substitute temperature gradient. This forecast was obtained by assuming a constant value of the thermal expansion coefficient of concrete with siliceous aggregate 
of $\alpha_{\theta}=1.05 \cdot 10^{-5} \mathrm{~K}^{-1}$. This is slightly higher than that used for room temperature analyses $\left(\alpha_{20 C}=1.00 \cdot 10^{-5} \mathrm{~K}^{-1}\right)$. On the basis of Fig. 9 , it can be concluded that, for the analysis of deformations of elements made of concrete with calcareous aggregate exposed to fire conditions, a good forecast would be provided by assuming a lower value of the concrete thermal expansion coefficient, e.g. equal to that used for calculations at room temperature.

The above values of the thermal expansion coefficient of concrete and the diagrams shown in Fig. 9 may only be used for the deformation analyses of unloaded elements exposed to fire. In heated and simultaneously heavily loaded elements, the strain of materials is different. In this case, the strain due to the decrease of the mechanical properties at high temperature must also be taken into account. Diagrams of the total strain of concrete and reinforcing steel under the influence of high temperature, depending on the stress ratio, can be found in $[6,21]$.

In the case of beams heated on three sides, the approximation used in the temperature gradient calculations, consisting in replacing the two-dimensional temperature field in the cross-section with a horizontal isotherm layout, had no significant effect on the calculated deflection values.

The higher the temperature gradient in the cross-section, the greater the deflection of the non-uniformly heated element. The largest growth in the tested beams' deflection occurred during the first 60 minutes of heating. After this time, the temperature gradient increase in the cross-section of the elements was insignificant, which resulted in a slow growth in deflection (Fig. 8).

After 120 minutes of exposure to high temperature, the deflection/span length ratio $(d / l)$ of the beams heated on three sides was about $1 / 160$, the temperature gradient in the cross-section was then about $890^{\circ} \mathrm{C}$, and the temperature at the place of the reinforcement was $850^{\circ} \mathrm{C}$. After 120 minutes of heating the beam on one side, the ratio $d / l$ reached the value of about $1 / 220$, the temperature gradient in the cross-section $-650{ }^{\circ} \mathrm{C}$ and the temperature at the place of the reinforcement - also $650{ }^{\circ} \mathrm{C}$.

Studies of simply supported beams, heated and loaded simultaneously, are presented in [5, 23-27]. The maximum deflection of the elements was about 1/43-1/12 of their span length, with the reinforcement temperature in the range of $500-700{ }^{\circ} \mathrm{C}$. The beams deformation caused only by non-uniform heating is about 5-10 times smaller than the total deflection of loaded elements with a heated tension zone. Therefore, a component resulting from free bending of the element caused by the temperature gradient may constitute about $10-20 \%$ of the total deflection of elements heated and loaded simultaneously. 


\section{SUMMARY AND CONCLUSIONS}

The paper presents a description and the results of free bending tests of reinforced concrete beams exposed to non-uniform heating at fire temperature.

In the case of elements both heated on three sides of the cross-section (a two-way heat transfer) and heated only from the bottom (a one-way heat transfer), good compatibility between the measured and calculated deflections of elements was obtained. The calculations were performed using the Maxwell-Mohr formula, in which:

- the elements were loaded with a substitute temperature gradient determined after dividing the non-linear temperature distribution in the cross-section into a linear component and the remaining "self-equilibrated" component (i.e. not causing any deformation of the element but only internal stresses in the cross-section);

- $\quad$ a constant value of the coefficient of concrete free thermal expansion of $\alpha_{\theta}=1.05 \cdot 10^{-5} \mathrm{~K}^{-1}$ was assumed.

It may be concluded that the method of determining free bending (thermal bowing) of the element presented in the paper is appropriate. This method can be used to separate the component arising from the thermal bowing phenomenon from the total deflection of the element exposed to the simultaneous action of load and high temperature.

An approximation consisting of replacing the two-dimensional temperature field in the cross-section of elements heated on three sides with a horizontal isotherm layout provided the appropriate results. The test results indicate that the component arising from the free bending of elements exposed to nonuniform heating at the fire temperature may constitute $10-20 \%$ of the total deflection of loaded elements with a heated tension zone.

The free deflection of the elements increases most intensively at the initial heating stage (in the tests performed - during the first 60 minutes), when the growth in the temperature gradient in the cross-section is the greatest. The increase in deflection stabilizes at the later heating stage.

\section{REFERENCES}

1. R. Kowalski, "Load bearing capacity calculation of bent RC elements in fire", Publishing House of The Warsaw University of Technology, Poland, 2008 (in Polish).

2 R. Kowalski, "Calculations of reinforced concrete structures fire resistance", Architecture Civil Engineering Environment. Journal of the Silesian University of Technology 2(4): 61-69, 2009.

3. R. Kowalski, M. Głowacki, M. Abramowicz, "On The Experimental Analysis of Temperature Influence on Stiffness of Reinforced Concrete Beams", Journal of Structural Fire Engineering 6(1): 49-57, 2015. DOI: $10.1260 / 2040-2317.6 .1 .49$ 
4 R. Kowalski, M. Głowacki, M. Abramowicz, "Premature Destruction of Two-Span RC Beams Exposed to High Temperature Caused by a Redistribution of Shear Forces", Journal of Civil Engineering and Management 23(4): 431-439, 2017. DOI: 10.3846/13923730.2016.1144645

5. G. M. Cooke, "Behaviour of Precast Concrete Floor Slabs Exposed to Standardised Fires", Fire Safety Journal 36(5): 459-475, 2001. DOI: 10.1016/S0379-7112(01)00005-4

6. R. Kowalski, "The Use of Eurocode Model of Reinforcing Steel Behavior at High Temperature for Calculation of Bars Elongation in RC Elements Subjected to Fire", Procedia Engineering 193: 27-34, 2017. DOI: 10.1016/j.proeng.2017.06.182

7. M. Abramowicz, R. Kisieliński, R. Kowalski, "Mechanical Properties of Reinforcing Bars Heated up Under Steady Stress Condition", Proceedings of International Conference Applications of Structural Fire Engineering, pp 31-36, Prague 2011.

8. R. Kowalski, R. Kisieliński, "On Mechanical Properties of Reinforcing Steel in RC Beams Subjected to High Temperature", Architecture Civil Engineering Environment, Journal of the Silesian University of Technology 4(2): 49-56, 2011.

9 Y. Anderberg, "Modelling Steel Behaviour", Fire Safety Journal 13: 17-26, 1988.

10. EN 1992-1-2:2004. Eurocode 2: Design of concrete structures - Part 1-2: General rules - Structural fire design.

11. R. Kowalski, R. Kisielinski, "Experimental approach to strength reduction and elongation of self-tempered reinforcing bars tensioned at a steady and an increasing temperature". Structural Concrete, Early View. DOI: $10.1002 /$ suco. 201800076

12. G. A. Khoury, C. E. Majorana, F. Pesavento, B. A. Schrefler, "Modelling of Heated Concrete", Magazine of Concrete Research 54(2): 77-101. 2002. DOI: 10.1680/macr.54.2.77.40895

13. G. A. Khoury, B. N. Grainger, P. J. Sullivan, "Strain of Concrete During First Cooling from $600^{\circ} \mathrm{C}$ under Load", Magazine of Concrete Research 38(134): 3-12, 1986. DOI: 10.1680/macr.1986.38.134.3

14. G. A. Khoury, B. N. Grainger, P. J. Sullivan, "Strain of Concrete During First Heating to $600^{\circ} \mathrm{C}$ under Load", Magazine of Concrete Research 37(133): 195-215, 1985. DOI: 10.1680/macr.1985.37.133.195

15. G. A. Khoury, B. N. Grainger, P. J. Sullivan, "Transient Thermal Strain of Concrete: Literature Review, Conditions within Specimen and Behaviour of Individual Constituents", Magazine of Concrete Research 37(132): 131-144, 1985. DOI: 10.1680/macr.1985.37.132.131

16. I. Hager, T. Tracz, "The Impact of the Amount and Length of Fibrillated Polypropylene Fibres on the Properties of HPC Exposed to High Temperature", Archives of Civil Engineering 56(1): 57-68, 2010. DOI: $10.2478 / \mathrm{v} .10169-010-0003-\mathrm{z}$

17. W. Jackiewicz-Rek, T. Drzymała, A. Kuś, M. Tomaszewski, "Durability of High Performance Concrete (HPC) Subject to Fire Temperature Impact". Archives of Civil Engineering, 62(4): 73-94, 2016. DOI: $10.1515 /$ ace-2015-0109

18. fib Bulletin 38/2007, "Fire design for concrete structures - materials, structures and modelling. State-of-art report", International Federation for Structural Concrete (fib), p. 97, 2007.

19. E. Jensen, J. Van Horn, J. Meenakshi, “Axial deformation of concrete exposed to fire and loading”, Proceedings, Interflam, Nottingham, UK, 2010.

20. C. Mindeguia, I. Hager, P. Pimienta, H. Carré, C. La Borderie, "Parametrical study of transient thermal strain of ordinary and high performance concrete", Cement and Concrete Research 48: 40-52, 2013. DOI: 10.1016/j.cemconres.2013.02.004

21. P. Chudzik, R. Kowalski, M. Abramowicz, "Strains of concrete in RC structures subjected to fire", Procedia Engineering 193: 377-384, 2017. DOI: 10.1016/j.proeng.2017.06.227

22. L. X. Xiong, "Uniaxial dynamic mechanical properties of tunnel lining concrete under moderate-low strain rate after high temperature", Archives of Civil Engineering 61(2): 35-52, 2015. DOI: 10.1515/ace-2015-0013

23. B. Wu, G-H. Tang, "Experimental Study on Fire Behaviors of Simply-Supported T-beams and Restrained T-beams", Proceedings of the 8th International Conference on Structures in Fire, Shanghai, China, pp 343-348, 2014.

24. E. G. Choi, Y. S. Shin, "The Structural Behavior and Simplified Thermal Analysis of Normal-Strength and HighStrength Concrete Beams under Fire", Engineering Structures 33(4): 1123-1132, 2011. DOI: $10.1016 /$ j.engstruct.2010.12.030

25. X. Shi, T-H. Tan, K-H. Tan, Z. Guo, "Influence of Concrete Cover on Fire Resistance of Reinforced Concrete Flexural Members", Journal of Structural Engineering 130(8): 1225-1232, 2004. DOI: 10.1061/(ASCE)0733-9445(2004)130:8(1225)

26. R. Kowalski, P. Król, "Experimental Examination of Residual Load Bearing Capacity of RC Beams Heated up to High Temperature", Sixth International Conference Structures in Fire, Michigan State University, East Lansing, Michigan, USA, Proceedings edited by V. K. R. Kodur and J. M. Fransen, DEStech Publications Inc., pp 254-261, 2010. 
27. B. Ellingwood, T. Lin, "Flexure and Shear Behavior of Concrete Beams during Fires", Journal of Structural Engineering 117(2): 440-458, 1991. DOI: 10.1061/(ASCE)0733-9445(1991)117:2(440)

28. Z. Guo, X. Shi, "Experiment and Calculation of Reinforced Concrete at Elevated Temperatures", Tsinghua University Press, Published by Elsevier Inc., 2011. DOI: 10.1016/C2010-0-65988-8

29. J. Yu, Y. Liu, Z. Lu, K. Xiang, "Flexural Performance of Fire Damaged and Rehabilitated Two Span Reinforced Concrete Slabs and Beams", Structural Engineering and Mechanics 12 (5), 2012. DOI: $10.12989 / \mathrm{sem} .2012 .42 .6 .799$

30. J. Franssen, "User's Manual for SAFIR 2011 A Computer Program for Analysis of Structures Subjected to Fire", University of Liege, Belgium, 2011.

31. EN 1991-1-2:2002. Eurocode 1: Actions on structures - Part 1-2: General actions - Actions on structures exposed to fire

32. R. Kowalski, M. Abramowicz, P. Chudzik, "Reaction of R/C Slabs Cross-Sections to Fire. Calculation of Simplified Substitute Temperature Loads Induced by An Unsteady Heat Flow", Proceedings of The International Conference of Applications of Structural Fire Engineering, pp 214-219, Dubrovnik 2015. DOI: $10.14311 /$ asfe. 2015.033

33. EN 1992-1-1:2004. Eurocode 2: Design of concrete structures - Part 1-1: General rules and rules for buildings

\section{LIST OF FIGURES AND TABLES:}

Fig. 1. Beams dimensions and reinforcement

Rys. 1. Wymiary i zbrojenie belek

Fig. 2. Beam location in the furnace chamber: a) beam heated on three sides, b) beam heated on one side (from the bottom), c) the test stand (furnace visible behind the beam)

Rys. 2. Usytuowanie belki w komorze pieca: a) belka ogrzewana $\mathrm{z}$ trzech stron, b) belka ogrzewana $\mathrm{z}$ jednej strony (od spodu), c) wygląd stanowiska badawczego (za belką widoczny piec)

Fig. 3. Location of the measuring equipment

Rys. 3. Rozmieszczenie aparatury pomiarowej

Fig. 4. Temperature measurement points in the cross-section of beam heated: a) on three sides, b) on one side (from the bottom)

Rys. 4. Układ punktów pomiaru temperatury w przekrojach belki ogrzewanej: a) z trzech stron, b) z jednej strony (od spodu)

Fig. 5. Temperature at particular points of the beam cross-section - comparison of test results and FEM calculations: a) beam heated on three sides, b) beam heated on one side (from the bottom)

Rys. 5. Temperatura w wybranych punktach przekroju belki - porównanie wyników badań i obliczeń MES:

a) belka ogrzewana $\mathrm{z}$ trzech stron, b) belka ogrzewana z jednej strony (od spodu)

Fig. 6. Isotherm layout in the beam cross-section heated: a) on three sides, b) on one side (from the bottom) Rys. 6. Położenie izoterm w przekroju belki ogrzewanej: a) z trzech stron, b) z jednej strony (od spodu)

Fig. 7. Linear components of temperature distribution in the beam cross-section heated: a) on three sides, b) on one side (from the bottom). Nonlinear temperature distribution (red line) and nonlinear "selfequilibrated" component (green line) after 60 minutes are presented Rys. 7. Liniowe składowe rozkładu temperatury w przekroju belki ogrzewanej: a) z trzech stron, b) z jednej strony (od spodu). Przykładowo po 60 minutach podano nieliniowy rozkład temperatury (linia czerwona) oraz składową nieliniową ,,samo-zrównoważoną” (linia zielona) 
Fig. 8. Comparison of the maximum deflection values obtained in the tests and calculated: a) beams heated on three sides, b) beams heated on one side (from the bottom)

Rys. 8. Porównanie wartości strzałki ugięcia uzyskanych w badaniach i obliczonych: a) belki ogrzewane $\mathrm{z}$ trzech stron, b) belki ogrzewane $\mathrm{z}$ jednej strony (od spodu)

Fig. 9. Free thermal elongation of concrete and steel [10]; estimation of the coefficient $\alpha_{\theta}$ Rys. 9. Swobodne wydłużenie termiczne betonu i stali [10]; oszacowanie współczynnika $\alpha_{\theta}$

Tab. 1. Temperature gradient, average cross-section temperature and comparison of deflections of the beams heated on three sides for 240 minutes

Tab. 1. Gradient temperatury, temperatura średnia w przekroju oraz porównanie ugięć belek ogrzewanych $\mathrm{z}$ trzech stron przez 240 minut

Tab. 2. Temperature gradient, average cross-section temperature and comparison of deflections of the beam heated on one side (from the bottom) for 120 minutes

Tab. 2. Gradient temperatury, temperatura średnia w przekroju oraz porównanie ugięć belki ogrzewanej z jednej strony (od spodu) przez 120 minut 


\section{SWOBODNE WYGINANIE SIĘ ELEMENTÓW ŻELBETOWYCH POD WPLYWEM NIERÓWNOMIERNEGO OGRZEWANIA}

Slowa kluczowe: belki żelbetowe, wysoka temperatura, pożar, ugięcie, zjawisko thermal bowing, gradient temperatury

\section{STRESZCZENIE}

W artykule przedstawiono opis i wyniki badań swobodnego wyginania się belek żelbetowych narażonych na nierównomierne ogrzewanie w temperaturze pożarowej.

Elementy żelbetowe ogrzewane nierównomiernie wyginają się na skutek swobodnej wydłużalności termicznej materiału, a wygięcie jest tym większe, im większy jest gradient temperatury w przekroju. W literaturze zjawisko to jest nazywane thermal bowing. Zachodzi ono niezależnie od obciążenia elementu. W statycznie niewyznaczalnych elementach zginanych może ono powodować powstawanie dodatkowych sił wewnętrznych, a w elementach ściskanych (słupach) zwiększenie mimośrodu siły podłużnej. W elementach wytężonych podczas ogrzewania, oprócz swobodnego wyginania się powstają jeszcze deformacje spowodowane pogorszeniem właściwości mechanicznych betonu lub stali.

W celu określenia, jaką część całkowitej deformacji wytężonego elementu ogrzewanego nierównomiernie od strony strefy rozciąganej może stanowić ugięcie wywołane zjawiskiem thermal bowing, przeprowadzono badania wyginania się nieobciążonych belek żelbetowych.

W sumie zbadano siedem belek o przekroju 160 x $200 \mathrm{~mm}$, długości $1300 \mathrm{~mm}$, wykonanych z betonu klasy C35/45 z kruszywem żwirowym (krzemianowym). Średnia wytrzymałość betonu na ściskanie oznaczona na próbkach sześciennych o boku $150 \mathrm{~mm}$ wynosiła odpowiednio 46,3 MPa - po 28 dniach od zabetonowania oraz 60,8 MPa - po około 4 miesiącach (przed przystąpieniem do badań). Średnia granica plastyczności stali określona eksperymentalnie wynosiła $560 \mathrm{MPa}$.

Belki ogrzewano na dwa różne sposoby:

(1) z trzech stron przekroju - zbadano 3 elementy; każdy ogrzewano przez 240 minut; w ten sposób symulowano belkę ogrzewaną od spodu i od strony powierzchni bocznych lub np. wolno stojący słup ogrzewany nierównomiernie; w przekroju tak ogrzewanego elementu występuje dwukierunkowy, nieustalony przepływ ciepła,

(2) tylko z jednej strony (zaizolowane powierzchnie boczne) - zbadano 4 elementy; czas ogrzewania wynosił 60, 120, 180 lub 240 minut; w ten sposób symulowano płytę lub ścianę ogrzewaną z jednej strony lub np. słup znajdujący się w ścianie o dobrych właściwościach izolacyjnych, ogrzewany z jednej strony; w przekroju tak ogrzewanego elementu występuje jednokierunkowy przepływ ciepła.

W artykule przedstawiono prosty sposób wyodrębnienia zastępczego gradientu temperatury oraz średniej temperatury w przekroju belek. W tym celu nieliniowy rozkład temperatury w elemencie, otrzymany w obliczeniach MES, przedstawiono w postaci sumy trzech składowych:

- $\quad$ liniowej równomiernej (średnia temperatura w przekroju),

- $\quad$ liniowej symetrycznej względem środka przekroju (zastępczy gradient temperatury) oraz

- $\quad$ nieliniowej, ,samo-zrównoważonej”.

Dwie pierwsze składowe wywołują odpowiedź termiczną konstrukcji jako całości. W przypadku ustrojów statycznie wyznaczalnych powodują ich wydłużenie lub wygięcie, natomiast w przypadku ustrojów statycznie niewyznaczalnych warunkują powstanie dodatkowych sił wewnętrznych. Trzecia składowa nie powoduje deformacji elementu jako całości, a jedynie jego wewnętrzne wytężenie. 
Wartości określonej eksperymentalnie strzałki ugięcia elementów porównano z obliczonymi za pomocą wzoru MaxwellaMohra. Jako dane do obliczeń przyjęto zastępczy gradient temperatury wyodrębniony z nieliniowego rozkładu oraz współczynnik rozszerzalności cieplnej betonu wynoszący $\alpha_{\theta}=1,05 \cdot 10^{-5} \mathrm{~K}^{-1}$. Wartość tę wyższą, niż w temperaturze pokojowej $\left(\alpha_{20 C}=1,00 \cdot 10^{-5} \mathrm{~K}^{-1}\right)$, oszacowano na podstawie temperatury panującej w przekrojach rozpatrywanych belek i eurokodowej zależności opisującej rozszerzalność termiczną betonu w temperaturze pożarowej. W belkach ogrzewanych z trzech stron dwuwymiarowe pole temperatury zastąpiono uśrednionym rozkładem izoterm równoległych do dolnej krawędzi przekroju elementu.

Zarówno w przypadku elementów ogrzewanych z trzech stron przekroju (dwukierunkowy przepływ ciepła), jak i ogrzewanych tylko od spodu (jednokierunkowy przepływ ciepła), uzyskano dobrą zgodność pomierzonych ugięć elementów z określonymi po przeprowadzeniu obliczeń (za pomocą wzoru Maxwella-Mohra).

Można wnioskować, iż przedstawiony w artykule sposób określenia swobodnego wygięcia elementu (thermal bowing) jest właściwy i może być wykorzystany do wyodrębnienia z całkowitego ugięcia elementu poddanego jednoczesnemu działaniu obciążenia i wysokiej temperatury, składnika pochodzącego od zjawiska thermal bowing.

Przybliżenie polegające na zastąpieniu dwuwymiarowego pola temperatury $\mathrm{w}$ elementach ogrzewanych $\mathrm{z}$ trzech stron przekroju uśrednionym rozkładem izoterm, zapewniło uzyskanie właściwych wyników.

Wyniki przeprowadzonych badań wskazują, iż składnik pochodzący od swobodnego wyginania się elementów narażonych na nierównomierne ogrzewanie w temperaturze pożarowej może stanowić 10-20\% całkowitego ugięcia elementów ogrzewanych od strony strefy rozciąganej przy jednoczesnym działaniu obciążenia.

Swobodne ugięcie elementów wzrasta najintensywniej w początkowej fazie ogrzewania (w przeprowadzonych badaniach przez pierwszych 60 minut), wtedy, kiedy wzrost gradientu temperatury w przekroju jest największy. W późniejszej fazie ogrzewania przyrost ugięcia stabilizuje się. 